\title{
DNA-Based Molecular Detection of Toxic Phytoplankton in Water Samples: Different Tools to Get Reliable Information
}

\section{Luca Galluzzi*}

Department of Biomolecular Science, section of Biotechnology, University of Urbino "Carlo Bo", Fano (PU), Italy

The harmful phytoplankton holds sanitary, ecological and economic implications towards the human health, the coastal environments, and aquaculture facilities due to the consequences of recurrent harmful algal blooms (HABs). The adverse effects of HABs include toxin production, fish gill clogging, oxygen depletion and unpleasant water quality. The HABs are phenomena increasing worldwide for several reasons: eutrophication and/or unusual climatological conditions, the increased utilization of coastal waters for aquaculture, the movement of resting cysts caused by human activities (e.g. ships' ballast waters or the translocation of shellfish stocks), and overfishing (1).

Nowadays, it is essential to have rapid, sensitive and reliable methods to be applied in monitoring programs of marine coastal ecosystems for accurately and specifically detecting HAB species. Such methods can allow investigating the HAB species distribution and dispersion mechanism, and facilitating the prevention or mitigation of the harmful effects on human health, marine ecosystem and economic related activities. In routine monitoring programs, the detection and quantification of harmful species are based on morphological recognition through microscope analyses, which are time consuming and require considerable taxonomic expertise. In fact, the presence of morphologically similar species co-existing in the marine environments (e.g. Pseudo-nitzschia spp.) or different morphotypes of the same species can sometimes affect the monitoring reliability. Moreover, in some cases the fixation by Lugol or formalin can cause a morphological cellular distortion. Nevertheless, the fixation processes are crucial to preserve samples during the time intercurring between sample collection and laboratory analysis.

Due to these limitations, many molecular methods for HAB species monitoring have been developed in the last years. Because of the instability of RNA (particularly mRNA) and proteins, most detection tools used for phytoplankton rely on detecting DNA. Target DNA sequences commonly used for developing specific primers and probes are rRNA genes, which are phylogenetically informative and tandemly repeated in high copy number.

Molecular approaches to species identification and quantification may be broadly categorized as "whole cell" or "lysed cell" methods. In the "whole cell" methods the cells remain intact throughout sampling and processing (e.g. FISH); in the "lysed cell" methods, cells are disrupted and the resulting cell homogenate is analyzed, typically with subsequent calibration of the fluorescence or colorimetric signal back to cell number (e.g. sandwich hybridization, microarray hybridization, real-time qPCR). Advantages of the "lysed cell" approaches for bloom monitoring include amenability to automation and the possibility to analyze larger environmental sample volumes, thereby avoiding errors inherent in the small sample size used for whole cell methods. Disadvantages include the fact that it is not possible to visually inspect samples (e.g. to verify that the positive results are not due to crossreactions with non-target organisms), and that all sources of target sequences can contribute to the signal (including senescent/dead cells or cells obscured in food vacuoles or fecal pellets).

No single type of molecular probe or assay strategy appears as the "best" a priori. Indeed, the choice of probes or molecular techniques for a given species in a geographical area is dependent by the number and genetic diversity of species/clades to monitor, the information needed (qualitative or quantitative), technical background and available laboratory equipment.

For example, microarray-based methods are very effective for the simultaneous large-scale detection of phytoplankton species in complex samples $(2,3)$. The advantages of this method rely in a high density of probes, high-throughput, small sample volumes, possible reuse of arrays, flexible assay design and possibility of species quantification $(4,5)$. However, focusing on the quantitative aspect, real-time qPCR may be considered the best method among the current DNA-based technologies for the molecular quantification of single microalgal species in both laboratory and field samples. The real-time qPCR is highly sensitive, specific, rapid, accurate, relatively affordable and can be applied to preserved environmental samples $(6,7,8)$. Multiplexing is possible (9), but it also introduces added complexity in the method development. Isothermal DNA amplification techniques, such as loopmediated isothermal amplification (LAMP) and nucleic acid sequencebased amplification (NASBA), are methods that could provide further advantages, because of their simplicity and low cost. All these methods also have the potential to be used in large-scale screening assays.

One issue of these DNA-based methods for cell detection is the primers/probes specificity. The design of a specific probe sequence is dependent on the availability of DNA sequence information in genome databases. Moreover, due to the genetic diversity present within certain species $(10,11)$ and the possible variations of target rRNA gene copy number among different strains (12), the methods should be optimized with the phytoplankton population in the geographical area to be investigated. To this end, non-molecular techniques, such as microscopy-based methods, can be combined with the DNA-based methods that need optimization.

Despite these aspects, DNA-based methods have shown many advantages compared to classical microscopy-based methods, including being more rapid, sensitive and specific at the species and population level, amenable to high throughput, and requiring a minor level of expertise in the routine laboratory procedures $(13,14)$.

The recent development of next generation sequencing (NGS) technologies has made affordable the sequencing of billions of genomic fragments extracted from environmental samples (15), therefore making NGS a potential tool for the large-scale diversity assessment and quantification of microorganims (16). NGS technologies have been applied in metagenomic diversity studies, in which individual

${ }^{*}$ Corresponding author: Luca Galluzzi, Department of Biomolecular Science, section of Biotechnology, University of Urbino "Carlo Bo", Fano (PU), Italy. Email luca.galluzzi@uniurb.it

Received June 12, 2012; Accepted June 12, 2012; Published June 14, 2012

Citation: Galluzzi L (2012) DNA-Based Molecular Detection of Toxic Phytoplankton in Water Samples: Different Tools to Get Reliable Information. Gene Technology 1:e101. doi:10.4172/2329-6682.1000e101

Copyright: @ 2012 Galluzzi L. This is an open-access article distributed under the terms of the Creative Commons Attribution License, which permits unrestricted use, distribution, and reproduction in any medium, provided the original author and source are credited. 
sequences (usually $18 \mathrm{~S}$ rRNA genes) are phylogenetically analyzed by comparison with well-defined DNA sequences available in databases (17). Moreover, these techniques can be also used to count short gene fragments (tags) purified from environmental samples, or PCR amplicons, to analyze the relative abundance of microalgal species. However, the NGS-based quantification is not completely reliable yet, because of some possible biases such as PCR-amplification bias or NGS reads.

DNA barcoding has also been used to assess phytoplankton diversity in marine environments. In particular, the cytochrome $c$ oxidase 1 (CO1) gene was shown to be informative as "barcode" to identify to the species level many dinoflagellate genera in environmental samples (18).

The operational cost and high-throughput of NGS technologies offer great potential for their future use in either discrimination and quantification of phytoplankton. However, NGS-based metagenomic studies on microalgae have shown that a large portion of sequence data cannot be assigned to any taxon because of an insufficient DNA taxonomic database. Therefore, thorough DNA databases have to be constructed in order to achieve a comprehensive understanding of the molecular diversity of microalgae in the environment, and to design reliable probes. Most data currently available in public databases have been derived from cultivable strains of microalgae. Since many microalgal species cannot be maintained in laboratory cultures, the single-cell genome analysis (19), in which the genome of a single microalgal cell isolated from the environment can be amplified and sequenced, could be the only manner to achieve this ambitious goal.

\section{References}

1. Granéli E, Turner JT (2006) An Introduction to Harmful Algae. Ecology of Harmful Algae 189: 3-7.

2. Gescher C, Metfies K, Frickenhaus S, Knefelkamp B, Wiltshire KH, et al. (2008) Feasibility of assessing the community composition of Prasinophytes at the Helgoland Roads sampling site with a DNA microarray. Appl Env Microbiol 74: 5305-5316.

3. Galluzzi L, Cegna A, Casabianca S, Penna A, Saunders N, et al. (2011) Development of an oligonucleotide microarray for the detection and monitoring of marine dinoflagellates. J Microbiol Methods 84: 234-242.

4. Ahn S, Kulis DM, Erdner DL, Anderson DM, Walt DR (2006) Fiber-optic microarray for simultaneous detection of multiple harmful algal bloom species. Appl Environ Microbiol 72: 5742-5749.

5. Diaz MR, Jacobson JW, Goodwin KD, Dunbar SA, Fell JW (2010) Molecula detection of harmful algal blooms (HABs) using locked nucleic acids and bead array technology. Limnol Oceanogr Methods 8: 269-284.

6. Galluzzi L, Penna A, Bertozzini E, Vila M, Garcés E, et al. (2004) Development of a real-time PCR assay for rapid detection and quantification of Alexandrium minutum ( a Dinoflagellate). Appl Environ Microbiol 70: 1199-1206.

7. Galluzzi L, Bertozzini E, Penna A, Perini F, Pigalarga A, et al. (2008) Detection and quantification of Prymnesium parvum (Haptophyceae) by real-time PCR. Lett Appl Microbiol 46: 261-266.

8. Toyoda K, Nagasaki K, Tomaru Y (2010) Application of real-time PCR assay for detection and quantification of bloom-forming diatom Chaetoceros tenuissimus Meunier. Plankton Benthos Res 5: 56-61.

9. Handy SM, Hutchins DA, Cary SC, Coyne KJ (2006) Simultaneous enumeration of multiple raphidophyte species by quantitative real-time PCR: Capabilities and limitations. Limnol Oceanogr Methods 4: 193-204.

10. Turrell E, Bresnan E, Collins C, Brown L, Graham J, Grieve M (2008) Detection of Pseudo-nitzschia (Bacillariophyceae) species and amnesic shellfish toxins in Scottish coastal waters using oligonucleotide probes in the Jellett Rapid TestTM. Harmful Algae 7: 443-458.

11. D'Alelio D, Amato A, Kooistra WH, Procaccini G, Casotti R, et al. (2009) Internal transcribed spacer polymorphism in Pseudo-nitzschia multistriata
(Bacillariophyceae) in the Gulf of Naples: recent divergence or intraspecific hybridization? Protist 160: 9-20.

12. Galluzzi L, Bertozzini E, Penna A, Perini F, Garcés E, et al. (2010) Analysis of rRNA gene content in the Mediterranean dinoflagellate Alexandrium catenella and Alexandrium taylori: implications for the quantitative real-time PCR-based monitoring methods. J Appl Phycol 22: 1-9.

13. Kudela RM, Howard MDA, Jenkins BD, Miller PE, Smith GJ (2010) Using the molecular toolbox to compare harmful algal blooms in upwelling systems. Prog Oceanogr 85: 108-121.

14. Medlin LK, Metfies K, Mehl H, Wiltshire K, Valentin K (2006) Picoeukaryotic plankton diversity at the Helgoland time series site as assessed by three molecular methods. Microb Ecol 167: 53-71.

15. Rothberg JM, Leamon JH (2008) The development and impact of 454 sequencing. Nat Biotechnol 26:1117-1124

16. Medinger R, Nolte V, Pandey RV, Jost S, Ottenwälder B, et al. (2010) Diversity in a hidden world: potential and limitation of next generation sequencing for surveys of molecular diversity of eukaryotic microorganisms. Mol Ecol 19 32-40.

17. Ki JS (2011) Hypervariable regions (V1-V9) of the dinoflagellate 18S rRNA using a large dataset for marker considerations. J Appl Phycol doi:10.1007/ s10811-011-9730-z.

18. Stern RF, Horak A, Andrew RL, Coffroth MA, Andersen RA (2010) Environmental Barcoding Reveals Massive Dinoflagellate Diversity in Marine Environments. PLoS One 5: e13991.

19. Yoon HS, Price DC, Stepanauskas R, Rajah VD, Sieracki ME, et al. (2011) Single-cell genomics reveals organismal interactions in uncultivated marine protists. Science 332: 714-717. 